Светлана Д. Младеновић" Народна банка Србије
821.111(73).09-31 Фокнер В. https://doi.org/10.18485/analiff.2019.31.2.5

Originalni naučni rad

Primljen: 12.04.2019

Prihvaćen: 19.08.2019

\title{
ХРОНОТОП РАЗАРАњА ИДИЛЕ У БУЦИ И БЕСУ'
}

\begin{abstract}
У раду се анализира Фокнеров роман Бука и бес кроз призму Бахтиновог хронотопа разарања идиле. Полазећи од жанровске окоснице романа, анализирају се теме које су испитиване и у другим критичким приступима, као што су јаз између субјективног и хронолошког времена, опозиција између природе и антиприроде, аутентичних и деградираних људских односа, урушење традиције без понуђених алтернативних погледа на свет - али са циљем да се редефинише првобитно „хронотопско“ виђење романа које је формулисао Сартр и које је до данас остало утицајно у критичкој литератури. Сартр је наиме први указао да је метафизика унутрашњег света Фокнерових романа у ствари метафизика времена, јасно показујући да он користи време како на садржинском, тако и на формалном плану да би обликовао уметничко-идеолошки смисао романа, који се у крајњој линији може исказати у терминима филозофске природе времена и виђења људске слободе. Закључак Сартрове анализе јесте да је Фокнер обезглавио време одузевши му будућност и да је његова метафизика метафизика апсурда или нихилизма, која не оставља простора за акт слободе. Уважавајући Сартрове увиде о природи времена у Буци и бесу, ми их постављамо у други оквир - бахтиновски хронотоп разарања идиле - чиме омогућавамо њихово радикално другачије читање.
\end{abstract}

Кључне речи: Бука и бес, хронотоп разарања идиле, време, Фокнер, Сартр, Бахтин

\footnotetext{
*_ svetlana.minic@gmail.com

1 Рад је настао у оквиру припреме докторске тезе „Хронотопи у великим романима Вилијема Фокнера из циклуса о Јокнапатофи“ која је одбрањена на Филолошком факултету у Београду, под менторством проф. др Радојке Вукчевић.
} 


\section{1. ХРОНОТОП БУКЕ И БЕСА}

\section{1. Жанровска окосница и хронотоп}

Бука и бес жанровски припада роману генерација, односно оној линији у европској романескној традицији која приказује пропадање и распад великих и моћних породица. Томас Мекхејни истиче да је, као и Сарйорис, и овај Фокнеров роман настао управо по моделу Буденброкових немачког модернисте Томаса Мана (McHaney y Bloom: 149). Међутим, као што истиче Иво Видан, важна специфичност је то што је „Фокнер заправо једини писац који је традицију и битну структуру генеалошког циклуса пренео у књижевност која се остварује модерним психолошким техникама“. Видан у томе налази „доказ о животној снази генеалошке теме, и о континуитету од свеприсутног приповједача у традицији реализма до уских обзорја кратковидне, неуротичне, чак субнормалне особе, као што је случај у Буцุи и бесу“" (81). ${ }^{2}$ Дакле, експериментишући у оквирима традиционалне тематике и структуре жанра генерацијског романа у овај свој роман Фокнер је унео низ новина на плану композиције и техника приповедања, а један од ефеката тог експеримента који нас посебно занима у овом раду јесте оно што је од Сартра надаље препознато као Фокнерова метафизика времена. Наиме, иако у Буц̧и и бесу време фигурира на тематском плану, још је Сартр показао да је неопходно узети у обзир како тематске, тако и формално-техничке одлике дела како би се дешифровало карактеристично поимање времена у овом роману које, по Сартру, крије кључ његовог уметничко-идеолошког смисла. Досадашња тумачења су ову метафизику најчешће настојала да растумаче полазећи од бергсоновске концепције времена. Ми

2 Неки критичари пак сматрају да резултат Фокнеровог експериментисања са овим традиционалним жанром није сасвим успешан. Харолд Блум (Harold Bloom) на пример, у предговору колекцији модерних критичких интерпретација Буке и беса, напомиње да је „Бука и бес помало исувише компликовано искована да би издржала свој прилично једноставан садржај, свој заплет породичних несрећа“ (Bloom 2008: 1). Он додуше признаје да сагу о Компсоновима спашава то што је ипак у питању сага и што је, као што је увек случај код Фокнера, прожима неки дубљи смисао, нека шира прича која „трансцендира четворо деце Компсонових, и прљавштине њихове породичне романсе“ (2). 
ћемо пак покушати да је растумачимо у светлу једног од Бахтинових жанровских хронотопа - конкретно хронотопа разарања идиле. Поћи ћемо наиме од чињенице да у Буц̧и и бесу Фокнер експериментише са формом породичног романа/романа генерација и од претпоставке да модификацијама унетим у ову традиционалну форму роман дугује своје главне уметничке ефекте, те ћемо кључ за дешифровање метафизике времена потражити у Фокнеровом поигравању са хронотопом разарања идиле, карактеристичним за овај жанр.

\section{2. Бахтинов хронотоп идиле и разарања идиле}

Хронотоп разарања идиле Бахтин разматра као подврсту идиличног хронотопа, који се у историји романа јавља у различитим облицима, а свима им је заједнички „идилични тип васпостављања древног комплекса и фолклорног времена“ (Бахтин 1989: 352). Основне одлике идиле су: јединство места и „вековна везаност живота поколења за једно место“, строга ограниченост идиле „само на основне малобројне реалности живота“ и јединство ритма људског живота са животом природе (353-354). Ова три главна момента су се испољавала у различитим варијацијама и са различитим интензитетом у идиличним романима (нпр. породичној идили и земљорадничкој идили), а пренета су и у романе новијег времена на које је идила утицала. Интересантна је веза проблема времена и идиле на коју указује Бахтин. Он наиме истиче да је форма идиле процветала управо у XIII веку, када је ,проблем времена у књижевности постављен веома оштро и јасно, када се будио нов осећај времена“ (355). Такође, „у неким идилама XVIII века проблем времена достиже филозофску спознају: право органско време идиличног живота овде се супроставља ужурбаном и растрзаном времену градског живота или чак историјском времену““ (355). За нас је релевантно на који начин је идилични хронотоп остварен у роману генерација. Бахтин истиче да је у овом жанру водећа тема пре свега „разарање идиле и идилично-породичних и патријахалних односа“ (360). Начин на који се тумачи ова тема зависи од „схватања и оцене разараног идиличног света“, као и од „оцене разорне снаге, то јест новог, капиталистичког света“ (360). Разарани идеалистички свет може да буде представљен, како Бахтин каже, „са извесном фило- 
зофском (русоовском сублимацијом)“, на пример кроз човечност идиличног човека и човечност у људским односима или интегритет идиличног живота (органска повезаност с природом, немеханизовани рад и сл). Истовремено се наглашава „ускост и затвореност идиличног микросвета“" (361) супротстављеног великом, али апстрактном свету, који карактеришу људска отуђеност и себично-практични односи, као и механизовани рад. Са темом човекове експатријације из идиличног света може бити повезана и тема његовог преваспитања за живот у новом, туђем и апстрактном свету (нпр. код Гетеа). У другој линији (чији су представници нпр. Стендал, Балзак, Флобер) приказан је пре свега слом идиличног гледања на свет, при чему ни идила ни капиталистички свет нису идеализовани.

Приказује се пропаст у условима капиталистичког центра провинцијског идеализма или провинцијске романтике јунака који нимало нису идеализовани; не идеализује се ни капиталистички свет: разоткрива се његова нечовечност, разарање свих моралних ослонаца (насталих на претходним ступњевима развоја), распадање (под утицајем новца) свих ранијих људских односа - љубави, породице, пријатељства [ ... ] Позитивни човек идиличног света постаје смешан, јадан и непотребан, он или пропада или се преваспитава и постаје себични грабљивац. (Бахтин 1989: 362).

\section{1. Хронотоп разарања идиле у Буци и бесу}

Бука и бес је у основи породични роман и роман генерација у коме се могу препознати кључне одлике хронотопа разарања идиле. У њему су пре свега присутне основне одлике идиле - јединство места и везаност сижеа за основне реалности свакодневног живота. Са изузетком Квентиновог поглавља, које приказује један његов дан на Харварду, додуше све време прожет сећањима на догађаје из детињства и младости проведене на породичном имању, остала три поглавља приказују свакодневицу Компосонових у породичној кући и на имању у Џеферсону (уз одласке послом у дућан, у школу, на гробље). Као што указује Андре Блекастан, стање куће симболички кореспондира са стањем породице, јер је овај некадашњи „емблем династичког по- 
носа“ постао „споменик пропадања и смрти“. „Судбина куће и њених укућана су лепо сумирани у Додатку, где Фокнер реферира на 'трулу породицу у трулећој кући'“ (Bleikasten у Bloom 2008: 45). Упркос вишегенерацијској везаности за своје имање, породица Компсонових је остала малтене без земље, више је не обрађује и нема делатни однос према њој. Бахтин даје такве примере у породичном роману и роману генерација где, упркос вези овог жанра са идилом, у њему може фигурирати породица отуђена од света природе.

Она је одвојена од уске феудалне локалности, од непроменљиве природне околине која ју је у идили хранила, од родних гора, поља, реке, шуме. Идилично јединство места, у најбољем случају, ограничава се породично-наследном їpagском кућом, нейокрейним делом капиталистичке својине. (Бахтин 1989: 359)

Везу са природом у виду продуктивног свакодневног рада (упрезање коња, цепање дрва, рад у башти, приправљање ручка и др.) налазимо још само код црначке послуге, док некадашњи делатни однос Компсонових према имању до нас допире само у облику подсећања на ранију генерацију плантажерских великопоседника, и то кроз израз Џејсоновог немоћног беса док становницима Џеферсона покушава да запуши уста: „Моји преци су кажем ја њима имали овде робове кад сте ви држали пиљарнице и кад вашу земљу ни последњи црнац не би узео у наполицу“ (Faulkner 2001: 237). Иронично је да ове речи изговара нерадник Џејсон који и сам ради у локалном дућану, а издржава се пре свега крадући новац намењен издржавању његове сестричине. Госпођа Компсон додуше жали што више није у стању да сама обавља послове у домаћинству, због чега је у потпуности зависна од своје послуге, али на основу сећања млађих Компсонових из периода њиховог детињства и Дилсине примедбе да нико не би јео њен чорбуљак чак и када би га приправила (Faulkner 2001: 267), јасно је да се она никада није бавила кућним пословима, а врло мало је учествовала чак и у подизању сопствене деце. Бенџијев пашњак, некада део природног света и породичног имања, уместо да послужи као улог који ће обезбедити Квентинову будућност, као будуће главе породице која ће се побринути за остале, постао је симбол траћења ресурса које је 
породица некада стекла. Идилична црта романа огледа се и у томе што сиже чине реалности свакодневног и породичног живота - смрт чланова породице (кроз три генерације), венчање и неуспео брак сестре Кеди, Квентиново самоубиство, поремећени породични односи и морално, психичко и физичко пропадање чланова породице (очев и ујка Моријев алкохолизам, мајчин егоцентризам и хипохондрија, Кедин и Квентинин промискуитет, Квентинова неуротичност, ескапизам и, коначно, самоубиство, Џејсонова себичност и грамзивост, Бенџијев интелектуални хендикеп). ${ }^{3}$ То наравно не значи да нам Бука $u$ бес не говори ништа о друштвено-политичкој ситуацији и културолошкој кризи на америчком југу 1920-их година - напротив, говори много тога, али пре свега на посредан - метафорички и симболичан начин, не бавећи се директно друштвено ангажованим темама ${ }^{4}$. Исто се може рећи и о расном питању - иако Фокнер у овом роману даје продубљену слику живота црнаца на Југу, однос Компсонових са црнцима из њиховог домаћинства пре свега је у функцији сликања поро-

3 Цртице о ширем социјално-друштвеном контексту допиру само кроз Џејсонове огорчене и циничне примедбе у вези са положајем фармера који гаје памук и берзанским шпекулантима, док ћаска са трговачким путником, или док се једи коцкајући се на берзи: „Жетва памука је у рукама шпекуланата. [...] Мислите да човек који се зноји око памука садећи га добија и цент више него што му је потребно да одржи голи живот“ [...] (Faulkner 2001: 104), „Дабоме, вода односи жетву из године у годину, а они тамо у Вашингтону траће сваког дана педесет хиљада долара на држање војске у Никарагви или где ти ја знам“ (233); или кроз Ерлов коментар о тешком животу сељака: „Нек с времена на време потроше коју пару и на позориште. Сељачки посао у брдским крајевима је тежак и не доноси богзна шта.“ (246).

4 Аспекте Буке и беса који дочаравају друштвену и културолошку кризу на југу 20-их година подробно описује Џозеф Сингал (Joseph Singal). Ипак, и сам Сингал напомиње, „по цену да понови оно већ познато“, да Фокнер свакако није писао роман „са намером да се упусти у културолошку анализу“, већ је инстинктивно унео увиде овог типа у наратив, проточивши своје „интутитивно разумевање културних дилема са којима су се он и његови јужњачки савременици суочавали“ у уметнички текст (Singal у Bloom 2008: 106). Клинт Брукс, који примећује да „пад породице Компсон представља врсту дегенерацију која се може јавити, и која се јављала било где, у било које време“ сматра да важност јужњачког окружења лежи у томе што се ова дегенерација много јасније и болније оцртава у патријахалном друштву, које је усредсређено на старинске вредности и на породицу (Brooks 1963: $341)$. 
дичних, а не расних односа ${ }^{5}$, као што су и Квентинова размишљања о његовом јужњачком пореклу и односу са црнцима, подстакнута његовом измештеношћу из родног краја за време студија на Оксфорду, у функцији приказивања његовог личног идентитетског расцепа.

Бахтиново запажање о позитивном човеку идиличног света, који у разореној идили „постаје смешан, јадан и непотребан, он или пропада или се преваспитава и постаје себични грабљивац“" (Бахтин 1989: 362) могуће је применити на сву компсоновску децу, укључујући и Квентин из наредне генерације. Кеди и Квентин су аутентични наследници старих Компсонових у идеализованом смислу - као носилаца правих врлина. Међутим, они поседују и личне особине које изазивају њихову трагичну судбину, тако да постају вољно-невољни изгнаници из породице и завршавају негде у далеком, туђинском свету, док урушено имање остаје на најнеспособнијим и најнемоћнијим изданцима породице (Џејсону и Бенџију). Карактеристично за урушење идиле, оно што би у неком другом контексту могло да представља добру особину, код Кеди и Квентина постаје извор слабости и неприлагођености. Јогунаста и непокорна Кеди, која је од све четворо деце имала највише иницијативе и смелости и била највише лидерски настројена, али и најспособнија да пружи и да прими љубав, своје незадовољство и бунт према дисфункционалној породици (егоцентричној и себичној мајци, неспособној да пружи љубав и оцу алкохоличару) изразила је тинејџерским промискуитетом ${ }^{6}$. Након нежељене

5 Ова поента се најбоље може илустровати улогом коју Дилси има у роману. Иако је несумњиво реч о индивидуализованом и снажном лику, као што Блекастан истиче, „њене врлине, онако како су представљене у роману, не дугују ништа раси“ (Bleikasten y Bloom: 52) и она у ствари представља контратежу Компсоновима.

6 Клинт Брукс је нпр. изричит поводом тога да је основни узрок пропасти породице Компсонових, шта год да би могли бити општији културни узроци, хладна и егоцентрична мајка: „Каролин Компсон није толико активно покварена и зла особа колико хладан терет негативности који парализује нормалне породичне односе“ (Brooks 1963: 334). Он у Кедином признању Квентину: „могла сам то да видим кроз њих како се кези на мене“ (Faulkner 2001: 124) види доказ да је Кедино понашање „опсесивно и компулсивно“ и да представља бег од њене породице (Brooks 1963: 341). Међутим, Гари Сторхоф даје врло уверљиву анализу којом показује да је у основи целокупне породичне патологије Компсонових очев алкохолизам (Storhoff у Bloom 2008: 81-111). 
трудноће и неуспешног покушаја да се она заташка браком, Кеди је изопштена из породице, а своју ћерку Квентин оставила је мајци и Џејсону на одгајање. Одрастајући у још хладнијем и себичнијем окружењу него некада њена мајка, Квентин ће такође бежати из школе и одати се промискуитету, да би коначно побегла од куће.

Кодекс породичне части, део Квентиновог јужњачког наслеђа, извргава се у своју сушту супротност у Квентиновој ригидној и стерилној интерпретацији, што га удаљава од реалистичног, мада циничног и дефетистичког става његовог оца и приближава егоцентричној крутости његове мајке. У основи његовог заштитничког и витешког импулса према Кеди налази се себичност и посесивност - жеља да је издвоји из стварног света са којим не уме да изађе на крај и да буде сам са њом, макар и у паклу. Као што није у стању да смисли неки конструктиван начин да олакша ситуацију у којој се нашла његова посрнула сестра, нема ни исправан осећај одговорности према породици. За разлику од Кеди, која свесно сноси последице својих грешака и налази какав-такав практичан одговор на новонасталу ситуацију (покушава да се уда да би заташкала ванбрачну трудноћу и спасила свој углед и углед породице, а касније издржава своју ћерку и стара се да она одраста у макар каквој породици, плаћајући за то високу цену - да са њом нема контакта), Квентин бира ексапизам. Иако глуми брата заштитника и главу породице изазивајући Долтона Емза на двобој, њега не интересује суштинска улога патријарха који треба да се побрине за породицу. Овај контраст између Кеди и Квентина јасно је приказан у њиховом разговору пред Кедино венчање, када је Квентин наговара да се не удаје за превртљивог Херберта:

Онда зашто мораш слушати ми можемо да побегнемо ти и Бенџи и ја где нико не зна где [...]

А чиме с новцем за твоје школовање с новцем добијеним од продаје пашњака да би ти могао отићи на Харвард зар не увићаш да сад мораш да завршиш ако не завршиш он неће имати ништа (Faulkner 2001: 134)

Артифицијелност и неприлагођеност Квентинових назора истакао је и Брукс, који у Квентину види типичан пример витешког љубавника који није дорастао својој витешкој и херојској улози, што је 
прозрела и Кеди, која га добро познаје. Она га види као „кихотовског малог брата кога треба сажаљевати, а не као неког кога се треба плашити или га поштовати“ (Brooks 1963: 336). Иако је, као најстарији мушки наследник, Квентин позван да буде чувар породичне части и имена, многи критичари су приметили како та улога много боље пристаје Кеди, која од детињства преузима лидерску и заштитничку улогу у односима са другом децом. Између ње и Квентина као да долази до замене родних улога, где Кеди уместо да прихвати улогу смерне јужњачке девице, бунтовнички и изазивачки користи своју сексуалност, док Квентин остаје сексуално спутан и неостварен (што се на патријахалном југу сматра срамотом). Квентина из његовог „витешког“ двобоја у који се запутио пешке и у коме се онесвестио као девојчица спашава Кеди, јашући на коњу.

Квентин и Кеди се грчевито држе свако за своју илузију која треба да надомести идилично јединство - Квентин најпре умишља да са Кеди може негде да побегне, а потом прибегава самоубиству да би сам побегао из стварног света 7 , а Кеди, будући да је принуђена да своју ћерку преда мајци и Џејсону на чување, грчевито се труди да себе одржи у самообмани да јој тиме обезбеђује породицу коју сама није у стању да јој пружи ${ }^{8}$. Иако су њих двоје неприлагођени и не сналазе се у разореној идили, међусобном љубављу и приврженошћу успевају да нам пренесу барем далеке одблеске идиличног света

7 Квентин међутим и сам наслућује да је његов покушај осуђен на неуспех, јер сасвим хамлетовски интуитивно осећа да спас од постојања није смрт, већ једино не родити се уопште: „Долтон Емз. Долтон Емз. Кад бих могао да будем његова мајка која лежи обнажена и издигнута тела смејући се, и да својом руком одгурнем његовог оца, гледајући га, посматрајући га како умире пре но што је и ступио у живот“ (Faulkner 2001: 95).

8 Гари Сторхоф (Gary Storhoff) са позиције теорије породичних система врло уверљиво објашњава понашање Квентина и Кеди, као и понашање свих Компсонових као „кодове стабилности“ којима покушавају да одрже привид стабилности и јединства у породици упропашћеној алкохолом. Није реч о здравим стратегијама, већ о стратегијама бекства којима се једна дисфункционална породица упушта у бесконачно понављање неуспешних алгоритама (бесконачна петља), или у „плес“, што је метафора којим терапеути дочаравају ритуализовано, ригидно и наизглед координирано понашање чланова овакве породице. (Storhoff: 1998 и Storhoff у Блоом 2008: 111-131). 
у коме је њихов брат Џејсон одувек био аутсајдер. Неспособан још од детињства да се руководи било чиме сем себичним интересом, у својим двадесетим годинама Џејсон постаје још јаднији и вреднији сажањења, док покушава да се прилагоди суровој стварности без трунке идеала, поставши „себични грабљивац“ (Бахтин 1989: 362). У свом опсесивном негирању било каквих идиличних вредности, он својим духовним сиромаштвом управо болно истиче одсуство разореног идиличног света. Џејсонова отуђеност од идиле једнако се огледа у његовој неспособности за емпатичан однос и љубав према било ком људском бићу, као и у његовој незаинтересованости за природу. Брукс истиче да га ове особине сврставају у плејаду Фокнерових зликоваца код којих се „недостатак љубави манифестује на два начина, два начина који се на крају своде на исту ствар: њихов однос према природи и према женама“ - Џејсон и једно и друго види само „као објекте којима може да манипулише“ (Brooks 1963: 339). Џејсоново непријатељство према природи у више наврата је подвучено и његовим циничним примедбама у којима и природне појаве и бића параноично посматра као саучеснике у завери против њега ${ }^{9}$, као када упада у незгоде док настоји да шпијунира своју нећаку по њивама око Џеферсона:

Био сам сав покривен чичком и гранчицама и свакојаким труњем, пуно ми их је било и одело и ципеле и све, и онда сам случајно погледао око себе и видео да ми се рука налази управо на отровном храсту. Једино нисам могао да схватим зашто је то само отровни храст а не змија или тако нешто. (Faulkner 2001: 239)

Одлучујући да остане нежења без деце, он уједно ускраћује породици продужење имена и негира природни поредак продужења врсте. Наглашавајући затворену субјективност целог романа, која у ствари представља „умирући свет“ старог поретка и има мало контаката са спољним светом „галопирајуће модерности“, Роберт Пен Ворен примећује да су једини аутсајдери који успевају да продру у мали круг Компсонових Кедини љубавници, а једини инсајдер који

9 Ово запажање - да Џејсон непрестано природним феноменима приписује магијске моћи, кривећи их за своје неуспехе, дугујем Сингалу (Singal y Bloom 2008: 100). 
успева да изађе и да функционише у спољњем свету је Џејсон (Кеди и Квентин додуше такође излазе, али „носећи своју пропаст са собом“ (253). Питајући се шта је овој четворици заједничко, Ворен открива да је то њихов однос према сексу и новцу. На питање шта спаја секс и новац у стварању ових Фокнерових „монструма“ он даје занимљив одговор, који се опет тиче односа према природи.

У седми круг пакла Данте смешта оне кажњене за злочине против природе, а међу њима су хомосекусалци и лихвари, јер се и једни и други огрешују о плодност природе. Са Фокнером, хомосексуалца можемо да читамо као: „онај који чини секс бесмисленим“ а лихвара као „финансијски капитализам“ - а грех, у оба случаја, јесте грех против реалности, грех апстракције, недостатак поштовања за природу који појединцу омогућава да са њом манипулише и да је нарушава. (Warren 1966: 253)

Као што се однос ликова према идиличним вредностима огледа у њиховом односу према природи, он се такође може читати и из њиховог односа према времену. Томас Мекхејни сумира у једној реченици оно што је већ постало опште место у критици Буке и беса: „Још један од психолошких проблема које Компсонови дечаци изгледа показују јесте да сваки има проблем са појмом времена. Бенџи не препознаје ток времена; Квентин жели да га заустави; док Џејсон избегава прошлост што је више могуће, живећи у ономе што изгледа као илузорна будућност“ (МсHaney у Bloom: 167). Брукс подсећа да једино Дилси поседује прави осећај времена - када кухињски сат откуца пет пута, она аутоматски исправља грешку и најављује да је осам часова (Brooks 1963: 328). У критици се често Дилсин осећај времена контрастира са Џејсоновим - полако и одмерено, она успева да посвршава све ствари у домаћинству на време, па и да стигне на службу у цркви, док Џејсон непрестано јури, али никад нигде не стиже. Овај контраст се може тумачити као супротстављање „органског времена“ идиличног живота ,ужурбаном и растрзаном времену градског живота“" (Бахтин 1989: 355).

Бенџи због своје интелектуалне ограничености није у стању да успостави хронолошку хијерархију међу својим искуствима и да са- 
дашњим утисцима да примат. Хронолошки след се код њега такмичи са емотивном јачином и квалитетом утисака, те можемо рећи да Бенџи на неки начин „побеђује“ време, јер му намеће поредак који има изражен субјективни печат. То не значи да он може да утиче на то који надражаји из спољне средине ће га задесити наредног тренутка, већ само да ће његов ум моћи да их потисне уколико превладају емотивно јаче обојени утисци из прошлости. То свакако није пожељан однос према времену, јер показује неадаптираност на реалност и пренаглашену рециклажу прошлости, те можда и одузимање смисленог и планског односа према будућности, на које упозорава Сартр.

Квентин пак на други начин није у стању да успостави хронолошку хијерархију и да садашњим утисцима да примат. Док је Бенџи ипак отворен за будућност - јер ко зна, можда се Кеди појави на наредни повик играча голфа на суседној ливади, Квентин је болно свестан да је Кеди какву жели заувек изгубљена и зато на крају бира да буквално уништи будућност, односно сваку могућност садашњости, сваки наредни тренутак, знајући да му она неће вратити Кеди његовог детињства. Главни утисак после читања Бенџијевог поглавља јесте јасноћа и живост прошлих утисака. Прошлост не умире, већ стално живи и обнавља се у Бенџијевој свести. Преовлађујући утисак на основу Квентиновог поглавља је пак немогућност успостављања тока времена. Сваки смислени ток се прекида Квентиновим опсесивнокомпулсивним асоцијацијама на смрт, Кедино губљење невиности, разговоре с оцем на ове опсесивне теме итд. Док је фрагментираност Бенџијевог времена изазвана непредвидивим, али ипак донекле афирмативним ерупцијама прошлости у садашњост, често на основу позитивних асоцијација, фрагментираност хронотопа код Квентина настаје насилним цепањем тока перцепције или резоновања, ерупцијом у садашњост нихилистичких опсесија („убијања“ сопствене сенке и Кединих љубавника, осећаја кривице и самокажњавања итд.). Код Бенџија и нема развијеног резоновања, па немамо утисак толико насилог прекида и осујећења успостављања хронологије као што је то случај код Квентина. Врхунац је Квентинова туча са Џералдом у којој је Квентин све време измештен из конкретне ситуације, конкретног простора и времена и у ствари замишља да изазива Кединог љубавника. На Шривово питање због чега је започео тучу и ударио Џе- 
ралда, Квентин одговара да не зна. Шривова запажања такође указују на његову потпуну одсутност:

Прво што сам видео било је кад си потпуно изненада скочио и рекао, „Јеси ли икад имао сестру? Реци?“ и кад је он казао Не, ти си га ударио. Приметио сам да га непрестано посматраш, али није изгледало да обраћаш и најмање пажње на било шта што се говори све док ниси скочио и упитао га има ли сестру. (Faulkner 2001: 173)

Квентин је опседнут временом, често у смислу покушаја да успостави механичку уређеност у својој расцепканој свести у којој нема целине, већ је ношена нихилистичким страстима.

У једном смислу однос ликова према времену у роману паралелан је са односом према болно одсутној а ипак свеприсутној Кеди. Иако интелектуално ограничен, Бенџи је са њом имао истински однос љубави и размене, што је аналогно његовој отворености према доживљајима који долазе, док Квентин, који такође носталгично жуди за идиличним светом, није способан да се са њим споји на Бенџијев непосредан и афирмативан начин, и подрива га својим нихилизмом и страшћу према смрти. У његовом дискурсу природа је стално подривена некрофилском тежњом ка апстрактној чистоћи коју жели да јој наметне. Као што жали за Кедином невиношћу у име апстрактног идеала породичне части (што је карикирано разговором са његовим оцем, који примећује да је то стање „као смрт: само стање у коме се други остављају“, те да су га људи измислили за жене (Faulkner 2001: 93), Квентин спроводи исто насиље над временом и природом. Као што викторијански и манихејски сатанизује пут, исто тако је неспособан и да се препусти тренутку и нерефлектованом доживљају, што му је отац саветовао предајући му дедин сат - да на тренутке заборави време („Дајем ти га не да те опомиње на време, него да би понекад за тренутак могао заборавити на њега и да не би трошио сву своју снагу упињући се да га освојиш“) (91). Његово поглавље почиње опсесивном усредсређеношћу на куцање сата, при чему осећа да га инстинктиван део његовог тела издаје. Узалуд окреће часовник лицем надоле, јер се по сенци прозорског оквира био увежбао да погоди време скоро у минут, „те сам морао да јој окренем леђа, осећајући да ме сврбе 
оне очи што су их некад животиње имале уврх главе на њеној задњој страни“ (92). Он у топлини сунца види сат који откуцава и прилику да га његово тело превари и наведе на нешто. „, Био је неки часовник високо горе на сунцу, и мени паде на памет како човека, кад нешто неће да уради, његово тело тера на то, некако несвесно“ (98). Сатови код часовничара који му у први мах звуче као попци у септембарској трави за њега такође симболизују прикривену замку и превару - њега не интересује колико је сати, већ да ли иједан од њих показује тачно време, да би закључио како један другоме поричу тачност. Током читавог монолога, опседнут је сликама замрзнутог покрета, никада као момената заборава и препуштања утиску, већ као грча замрзнуте слике. Као што се често истиче, ове слике се могу тумачити као Квентинова жудња да загосподари бергсоновским трајањем (његови идеали у том погледу су речна пастрмка или Џералд Бланд, који господаре речним флуксом) (Singal y Bloom 2008: 87). Међутим, његови покушаји изјаловљују се у наметање ригидних образаца и вештачке сталности животу, и коначно у самоубиство. „Када коначно уђе у ток реке, то неће бити као веслач или пливач који се без напора креће кроз њу, већ са две гвоздене пегле привезане за његово тело, због којих ће потонути на дно као камен“ (Исто: 87).

Поред коришћења времена у карактеризацији, Фокнер га је дубоко уплео и у наративну конструкцију. Време нам наиме помаже да разумемо и Фокнерово претумбавање приче и структурна средства којима је остварено јединство у овој модернистички намерно ишчашеној причи. Ову употребу први је детектовао Сартр.

\section{2. САРТРОВА КРИТИКА И РЕИНТЕРПРЕТИРАҢЕ МЕТАФИЗИКЕ ВРЕМЕНА БУКЕ И БЕСА}

\section{1. Време у Буци и бесу}

У свом есеју „Поводом 'Буке и беса': темпоралност код Фокнера“, Сартр препознаје две главне специфичности наративне презентације времена у Буции и бесу, јасно осећајући да у њима треба тражити пишчеву метафизику или визију која ће нам разјаснити и његов 
наративни поступак. Прва специфичност је напуштање хронолошког следа у представљању догађаја.

Читалац осети потребу да нађе неке реперне тачке и да за себе успостави хронологију: Џејсон и Каролина Компсон имали су три сина и једну кћер. Кћер, Кеди, подала се Долтону Емзу и остала у другом стању; приморана да брзо потражи мужа... Ту се читалац зауставља, јер примећује да прича неки други роман: Фокнер није прво замислио ту сређену интригу да би је затим измешао као шпил, карата, он није могао да прича друкчије него што је то учинио. (Sartre 1984: 187)

Ова прва одлика, одустајање од хронолошког следа у представљању догађаја типична је не само за Фокнера, већ за модернистичку прозу уопште и представља најочигеднију иновацију у идиличном хронотопу/хронотопу разарања идиле. На њу на пример указује Стивенсон (Randall Stevenson) када упоређује дело Џојса и Вулфове са буиляунїсроманом како би илустровао „модернистички бег од живота као серије“:

Прогресивни, секвенцијални развој Буиляуні̄сромана, на пример - праћење живота његовог централног лика, корак по корак, током много година од рођења до зрелог доба - значајно је другачији од дела Џојса или Вулфове, који своје протагонисте прате током само једног дана у Уликсу (1922) или Госйођи Даловеј (1925). (Stevenson 1992: 87)

И Фокнер своје протагонисте прати током само једног дана, сажимајући помоћу сећања читав њихов живот у низ испретумбаних епизода. Међутим, друга специфичност наративне презентације времена у Буции и бесу на коју је указао Сартр и која је од првих дана живота романа фасцинирала и интригирала критичаре јесте намерно замућена граница између два временска плана - прошлости и садашњости у Бенџијевом и Квентиновом поглављу, уз специфично фаворизовање прошлости.

Крајње необичан ефекат Фокнерове прозе у прва два поглавља критичари су покушали да изразе на различите начине. Сартр Фокнерову садашњост у овим поглављима описује као лопова који 
се прикрада и изненада нестаје, или пак истиче да је пуна пукотина кроз које је прошлост преплављује. Жан Пуијон пак овај ефекат описује као толико непосредну, нерефлектовану уроњеност ликова у прошлост, да она постаје ,једина реалност“. Он такође ову прошлост назива „екстратемпоралном“, јер у потпуности трансцендира временски след. Сартр је сматрао да је Фокнерова романсијерска техника логичан исход Прустове метафизике, једино што је „Пруст класичар и Француз: Французи се губе само на махове и увек се на крају поново налазе“ (191). Из тог разлога, Пруст налази спас у „интегралном васкрсавању прошлости“, док „за Фокнера прошлост, насупрот томе - на несрећу - никад није изгубљена, она је увек ту, то је једна опсесија“ (190). Та прошлост је „индивидуалнија и неодређенија“ него на пример у Сарйорису где је била бенигније представљена, у виду историје породичних и конструисаних успомена, и „намеће се тако снажно да понекад прикрије и садашњост“ (189). Сартр је сматрао да је Фокнеров захват део општег књижевног феномена његовог доба, тежње писаца да „осакате“ време, на различите начине - било свођењем на интуицију тренутка, или тако што стварају од њега ,једно мртво, закључено памћење“. Пруст и Фокнер су га, по оцени Сартра, „напросто обезглавили - одузели су му будућност, то јест димензију делања и слободе“ (191).

Поред поменутог стилског и структурног фаворизовања прошлости, чиме она у наративној презентацији добија већу тежину од садашњости, Сартр своју тезу о Фокнеровој нихилистичкој метафизици гради и на једној недовољно заснованој претпоставци - да Фокнерови јунаци ни не размишљају о будућности. Међутим, то што је Квентин опседнут духовима прошлости у тој мери да све одлучније намерава да почини самоубиство и на крају то и чини не значи да се он у неком моменту није могао предомислити. За разлику од Сартра, који сматра да „Квентинови монолози и његова последња шетња већ јесу Квентиново самоубиство“ (191), Маргарет Д. Бауер (Margaret D. Bauer) на пример сасвим другачије тумачи Квентинов последњи дан: „Да, Квентин јесте планирао да почини самоубиство све време, али ја тврдим да он тражи разлог да га не почини, испитујући своја сећања у нади да она неће открити оно што почиње да увиђа: његову истинску, а не умишљену улогу у пропасти Кеди“ (Bauer у Bloom 2008: 77). 
Маргарет Бауер иначе нуди врло уверљиву анализу, јер Квентиново увиђање сопствене кривице делује као психолошки прихватљивији разлог за његово самоубиство од многих других које су критичари понудили ${ }^{10}$.

Показаћемо да Фокнеров третман времена у Буц̧и и бесу, пре него одраз једне нихилистичке метафизике, представља појачавање и иновирање традиционалног хронотопа разарања идиле структурним и стилским средствима. Као и увек код Фокнера, традиционални елементи, у овом случају породичног/генерацијског романа и хронотопа разарања идиле искоришћени су у измењеном оквиру и главни њихови ефекти произлазе из ове измештености. Наиме, оно на шта се недовољно обраћала пажња, а од чега у ствари треба почети, јесте сврха ове метафизике времена - по нашем мишљењу, она представља иновативан начин за рекреирање изгубљеног идиличног света.

\section{2. Рекреирање идиличног света}

Својим у то време иновативним приповедним поступцима - бирајући технику тока свести да прикаже поглед на свет интелектуално хендикепираног Бенџија и неуротичног и суицидалног Квентина, Фокнер успева да дочара специфичан доживљај времена који на посебан начин гради хронотоп разорене идиле. Идилични свет кога више нема није смештен у идеализовану прошлост „почетака и врхова“ (Бахтин 1989: 447), већ непрестано неочекивано искрсава у Бенџијевој свести, призван асоцијацијама, и еруптивно избија у Квентиновој, провоциран његовим опсесивним размишљањима и изгонећи његову садашњост. Сартр је заиста био у праву када је рекао да се Фокнерова визија у Буц̧и и бесу може упоредити са оном коју има човек кад у отвореном ауту гледа уназад, јер му садашњост - слике које му промичу пред очима, личе на треперење, безобличне сенке и конфете

10 Неке од тих разлога сумира Бауер на почетку свог чланка: „Теорије се разликују међутим у погледу тога шта тачно из Кединог односа са Долтоном је толико поражавајуће за Квентина: неки верују да је то Кедино губљење невиности, симбола породичне ласти; други мисле да је то што је Квентин изгубио Кеди због другог човека; трећи тврде да је у питању Квентинов страх да ће заборавити свој бол због Кединих дела; а четврти пак закључују да је то откриће његове сопствене импотенције и импотенције кодова по којима живи“ (Bauer 2000: 70). 
светлости, док једино прошлост - слике на одстојању имају чврсте и јасне обрисе. Могуће је, међутим, да је погрешно разумео Фокнерову мотивацију у примени овог поступка. Фрагментиране и збркане слике из Бенџијевог и Квентиновог поглавља такве су јер је писац намерно желео да из њих издвојимо само једну јасну слику - слику идиличне прошлости. Тај идилични свет оличен је у одсутности Кеди, која представља најблискију и најтоплију личност из Бенџијевог и Квентиновог детињства, проведеног у безбрижној игри на имању и у породичном дому, док су још сви били на окупу. Ово је верзија идиличног хронотопа у којој Бахтин препознаје извесну филозофску (русоовску) сублимацију - у њему се разарани идилични свет не приказује као део све даље феудалне прошлости, већ се „у први план уздиже дубока човечност самог идиличног човека и човечност у међуљудским односима, затим интегритет идиличног живота, његова органска повезаност с природом“ (Бахтин 1989: 361). Већина сцена у којима се Бенџи и Квентин присећају Кеди смештена је у природном окружењу - у потоку и пашњаку на коме су се као деца играли или дворишту у коме су изводили несташлуке, попут пењања на крушку са које су шпијунирали одрасле. За Бенџија Кеди је истовремено синоним за топао људски однос и за природу. „Кеди је клекла и обавила руке око мене и своје хладно лице које је зрачило притисла уз моје. Мирисала је као дрвеће.“ (Faulkner 2001: 30). Она једина покушава да успостави истински дијалошки однос са Бенџијем, стално му упућујући питања и симулирајући разговор, упркос томе што је свесна његовог хендикепа - као у случају када успева да погоди да га иритира њен парфем ${ }^{11}$. „„,Ах.“ рекла је. Спустила је бочицу и пришла ми и загрлила ме. „То је дакле. Покушавао си да то кажеш Кеди а ниси могао да јој кажеш. Желео си, али ниси могао, је ли да да ниси могао. Разуме се да Кеди неће. Разуме се да Кеди неће. Причекај само да се обучем.“(61). Идилични свет је за Бенџија истоветан са емотивном инвестираношћу у Кеди, па отуд и животност и упечатљивост сећања из времена док је она још живела у породици. То је уједно и централна порука Бенџијевог поглавља - разлог зашто Фокнер причу о Компсоновима уводи кроз монолог једног идиота није само да би читаоца заинтригирао

11 Ову важну чињеницу Кединог дијалошког односа према Бенџију истакла је Стејси Бартон у својом бахтиновском читању Буке и беса. 
и структурално га увукао у конструисање приче, већ пре свега стога што му је стало да из збуњујућег калеидоскопа његовог унутрашњег живота понесемо један важан општи утисак. Бенџијево поглавље је наиме најнепосреднији израз носталгије за једним светом, оличеним у Кеди. Као што истиче Лоренс Томсон (Thomson Lawrence):

Беново наизглед хаотично сањарење у првом поглављу Буке и беса Фокнер је тако смислио да би усмерио пажњу не само на фрагменте читаве приче о Компсоновима, већ посебно на Бенџијеву све-обузимајућу љубав према Кеди која је постојала и (као и огледало) сада је нема. Њено присуство је радост за Бена; њено одсуство је његова туга; њен могући повратак је нада. (Thomson у Hoffman, Vickery 1963: 214) ${ }^{12}$.

Квентинов идиличан - идеализован свет такође је оличен у сећањима везаним за Кеди. И у Квентиновим сећањима Кеди је у симбиотском односу са природом, само што због подвојености његове свести ове асоцијације узимају вид два супротна екстрема, по линији викторијанског морала, те су слике или идеализоване (у асоцијацијама на венчање, она истрчава право из огледала, из облака мириса, окружена ружама) (Faulkner: 92) или манихејски унижене (када је нагласак на нагонском и на сексуалности: „зашйо мораш йо gа чиниш као ирнкиња йо йољима јариима мрачним шумама расйаљеним скривеним йомамним йо мрачним шумама“" (106)). Најдужа сцена из његовог поглавља у којој се он и Кеди свађају због Долтона Емза, лежећи у потоку, стилски је обликована као песма у прози и по свему наликује на сусрет, свађу због љубоморе и међусобно поверавање двоје љубавника, па чак, како се често истиче, симулира и сексуални чин. У тој

12 Иако се слажемо са Томпсоном када је реч о суштинској поруци Бенџијевог поглавља, другачије тумачимо структурну поделу Буке и беса. Томпсон наиме сматра да позитивни углови гледања Бена и Дилси „буквално и симболично стављају у заграде и садрже два негативна угла гледања која рефлектују Квентин и Џејсон у другом и трећем поглављу“, чиме је појачана главна тематска антитеза између „ефеката самозаљубљености која производи хаос и ефеката саосећајне и самопожртвоване љубави која производи ред у људском искуству“ (225). У нашем читању хронотопа разорене идиле пак прва два поглавља тематски и стилски су сродна јер дају фрагментиране одблеске идиличног света, док друга два, која су са њима стилски контрастирана, приказују пустош разорене идиле. 
сцени Квентинов и Кедин дијалог испреплетан је, на неким местима сасвим неодвојиво, од природног амбијента у коме се одвија. ${ }^{13}$

лице јој је било бледа мрља која се захваљујући њеној коси издвајала на белини песка

$[\ldots]$

прешао је све океане обишао је цео свет онда је говорила о њему обујмивши своја мокра колена лица забаченог у сивој светлости мирис козњака видела се светлост у маминој и у Бенџијевој соби где га је Ти-Пи полагао у постељу

$[\ldots]$

не ваља то што чиниш зар не знаш да не ваља пусти ме козњак је сипао и сипао као измаглица могао сам да чујем зрикавце како нас у кругу посматрају она је узмакла обишла ме и упутила се дрвећу (Faulkner 2001: 160-161)

Блекастан је приметио да је у Бенџијевим и Квентиновим сећањима Кеди изједначена са свим природним елементима - земљом, ватром, ветром, а пре свега водом. Хронотоп разорене идиле, остварен помоћу Кединог лика, може се повезати и са једном од латентних митолошких потки Буке и беса - са митом о Персефони, који има корене у прородном циклусу смрти и обнављања вегетације. Кедин одлазак из куће Компсонових да се уда за Херберта Хеда симболички представља отмицу од стране Хада, бога подземног света. За њом остаје пустош, због жалости њене мајке Деметре, богиње плодности (како физичка, јер је домаћинство у време када Кеди ту више не живи остало и без пашњака који је продат за Квентиново школовање, тако и емотивна - пре свега у срцима Бенџија и Квентина; такође, Квентин извршава самоубиство управо након Кединог венчања). Као што указује Томас Мекхејни,

13 Занимљиво је да је управо овај одељак Квентиновог поглавља Фокнер написао у истом креативном замаху када и Бенџијево поглавље. Наиме, као што је Гејл Морисон (Gail Morrison) показао на основу детаљне анализе различитих верзија рукописа Буке и беса, у иницијалној верзији друго поглавље почињало је свађом између Квентина и Кеди у потоку, поводом њеног првог љубавника, Долтона Емза (на шест страна), али га је Фокнер касније преместио, одлучивши да понови структурни образац из Бенџијевог поглавља, који ће потом такође применити и у Џејсоновом (не почиње in medias res, већ има структуру јутро - подне - вече одређеног дана). (Morrison y Bloom 2008: 16-17) 
аспекти приче о Персефони се евоцирају управо у Бенџијевом и Квентиновом поглављу (McHaney у Bloom 2008: 164) ${ }^{14}$. Тематска и стилска сродност прва два поглавља у смислу живог евоцирања сећања на Кеди на такав начин да се малтене ре-креира њена присутност (с обзиром на специфичност Бенџијевог и Квентиновог унутрашњег преживљавања), која је у оштром контрасту са друга два поглавља у којима Кеди не живи више међу Компсоновима и у којима преовлађује реалистична дистанца или хладан став према њој могу се симболички повезати са сменом сезона у миту о Персефони, јер је њена мајка успела да је отме од Хада, али само на првих шест месеци у години, док је наредних шест месеци Персефона принуђена да се враћа у подземни свет.

Блекастан у свом тумачењу Кединог лика такође потврђује две црте које сматрамо важним за рекреирање идиличног света - непосредност и утопијски квалитет приказа Кеди. Он примећује изузетну живост и пластичност сећања којима се Кеди рекреира.

Дрвеће, вода, сумрак, орлови нокти - све слике природе повезане са Кеди, далеко од тога да привлаче пажњу на себе на начин симбола, чини се да израстају из плодног тла субјективног искуства, док су истовремено нераздвојно повезане са осетилним светом. Никад се не стврдњавају у фиксне обрасце алегорије, њихов вишеструки симболизам произлази из динамичне размене између јаства и његовог окружења. (Bleikasten 1990: 1531)

Блекастан упозорава да и поред тога што Кеди представља стваран лик и имамо довољно информација да о њој изградимо слику као о стварној особи, њеној психологији и моралности на пример, то би значило промашити Фокнерову поенту. Његово тумачење Кединог лика такође ставља нагласак утопијску црту, коју тумачи и као поруку Фокнерове књижевне естетике.

Кеди је била неухватљива за њеног творца; таква је и за своју браћу у роману, и таква мора остати за читаоца. Она се не може оцењивати истим критеријумима као и други ликови, јер у крајњој линији она припада другом простору, ономе што

14 О миту о Персефони у Буци и бесу види такође Doreen Fowler y Fowler, Abadie 1991:140-156. 
се може назвати утопијом романа. „Истински живот је одсутан“, писао је Рембо. Кеди је патетичан емблем тог жељеног другог живота, док њена судбина болно потврђује његову немогућност у свету отуђења и болести [...] Њена присутност/ одсутност у центру и на периферији романа сигнализира неиспуњеност пишчеве жеље, као и неизбежну недовршеност његовог дела. (Bleikasten 1990: 1554).

Ми међутим не бисмо протерали Кеди у тако далеку утопију као што је неуспех језика да изрази искуство. Таква тумачења се углавном заснивају на Фокнеровим аутобиографским изјавама о томе да му је лик Кеди био сувише драгоцен да би га директно приказао (те је зато одабрао да је прикаже кроз монологе тројице браће Компсонових), да је представљала његову чежњу за сестром коју никада није имао и за ћерком коју је изгубио по рођењу или о томе да је, као његово најзахтевније списатељско чедо, овај роман представљао његову тежњу за књижевним савршенством (његову „римску вазу“) ${ }^{15}$. Стејси Бартон је у свом бахтиновском читању Буке $и$ беса указала да је неопходан опрез код оваквих тумачења, јер се у превеликој мери ослањају на Фокнеров ауторски глас којим је накнадно покушавао да контролише свој иницијално разноречни и полифони роман ${ }^{16}$. Кеди је била важна, ако не и најважнија особа у животу Бенџија и Квентина, а њене особине учиниле су је погодном постане симбол свега што су изгубили у односу на период детињства (не само топлине и сигурности, већ и породичне части и бољег материјалног статуса), па и пројекција оног што никада нису имали. Као што је Бахтин истакао, идила познаје овај механизам којим се цео систем вредности, читав један свет може персонализовати и свести на међуљудске односе.

15 О овим и другим Фокнеровим изјавама којима је митологизовао Буку и бес, види нпр. код Дејвида Минтера или Блекастана (Minter 2001, Bleikasten 1990).

16 Бартон истиче да је Фокнер у накнадним изјавама и интервјуима настојао да митологизује Буку и бес приписујући јој централно и мистериозно место у својој каријери и при том намећући сопствена тумачења ликова (посебно у Додатку додатом 16 година након објављивања романа). Примећујући да је критика великим делом некритички усвојила овај накнадно додати ауторски глас, Бартон шаљиво примећује да аутор у фокнеровским студијама изгледа никада није умро. (Stacy Burton: „Rereading The Sound and the Fury“, 2001) 
Поред тога што је специфичном конструкцијом монолога Бенџија и Квентина (пре свега сменом временских планова) Фокнер изградио утисак континуираног јављања и нестајања - истовремене присутности и одсутности идиличног света, он је овај ефекат додатно појачао и на плану ширих композиционих целина, стилским контрастима између поглавља романа. Наиме, како је још Брукс истакао, прва два поглавља „по општој структури подсећају на дела о расположењу, чак и на песме о расположењу, пре него на наративне трансакције“ (Brooks 1963: 345) ${ }^{17}$. Специфичним стилом у прва два поглавља Фокнер нам је отворио прозор у идилични свет, док последња два представљају отрежњење. Иако у првом поглављу врло брзо постајемо свесни да стичемо увид у унутрашње доживљаје једног идиота, људскост и топлина света који нам он дочарава чине да на тренутак заборавимо његову интелектуалну ускраћеност, у тој мери да реалистичан опис Бенџијевог спољашњег изгледа, који Фокнер даје тек у четвртом поглављу, звучи као груба дефамилијаризација:

Чула је кораке кроз трпезарију, а онда су се врата расклопила и појавио се Лестер, а за њим један грмаљ који као да је био саздан од неке материје чије честице нису хтеле или нису могле да се сложе једна с другом нити са скелетом који је носио. Лице му је било ћосаво и као у мртваца; патећи и од водене болести, вукао се и гегао при ходу као припитомљен медвед. Коса му је била светла и нежна, глатко очеткана низ чело као деци на старинским фотографијама. Имао је јасне очи, питоме и бледоплаве као пољско цвеће, дебела доња усна му је висила опуштена, и слузила помало. (Faulkner 2001: 269)

Наша затеченост се пак претвара у потпуну неверицу у последњој сцени романа у којој је Бенџи приказан у најекстремнијој

17 Харолд Блум пак негативно оцењује Фокнеров стил у прва два поглавља, са становишта карактеризације ликова: „Само је Џејсон, од свих Компсонових, довољно индивидуалан да се задржи у сећању читаоца. Његова дикенсовска поквареност чини Џејсона карикатуром вредном дивљења, док се Квентин, Кеди и Бенџи утапају у континуум, фигуре мисли за које Фокнер није успео да нађе неизбежне фигуре говора““. (Bloom 2008:1) 
манифестацији своје интелекуалне ограничености и ригидности, док ужаснуто урла у моменту када Лестер са колском запрегом скреће улево уместо удесно ${ }^{18}$. Сматрамо да се снажан ефекат ове дефамилијаризације најбоље може објаснити контрастом са верно рекреираним идиличним светом. Представу о Бенџију смо наиме иницијално изградили као део опште слике у којој су топли људски односи, разумевање и комуникација приказани као реална могућност. У неку руку се може рећи да се тек са овом последњом сценом у потпуности распада идилично јединство креирано у Бенџијевом поглављу - непорецивим подсећањем у чијем уму је створена ова афирмативна целина. Наглашавајући компулсивно и бесмислено инсистирање на устаљеном поретку ова сцена асоцира на анти-природу, аутоматизованост и смрт и понавља утисак са краја Квентиновог поглавља - ситуацију у којој се он ригидно придржава устаљеног редоследа док се педантно дотерује за сусрет са смрћу. У том завршном моменту са ужасом схватамо да смо управо били сведоци последњег дана у животу једног самоубице. Потпуно сива и макабрична атмосфера нас међутим још више обузима након примедби гђе Компсон о Квентиновом самоубиству и Џејсоновог црног хумора на ту тему, највише због себичне и материјалистичке перспективе из које они посматрају овај Квентинов трагичан чин, у којем су изгубили члана породице.

Када је реч о атмосфери четвртог поглавља, насупрот гледиштима која га тумаче као позитивно завршавање/уоквиравање романа (дајући централну важност проповеди велечасног Шегога), сложили бисмо се са Блекастановом анализом (из чланка са индикативним насловом: „Ускрс без ускрснића?“(19) у којој он упозорава да стил и језик којима се описују ликови и физичко окружење у четвртом поглављу наводе

18 Познато је да у другим интерпретативним оквирима ова сцена добија сасвим другачије тумачење. Томсон тумачи Бенџија као морални репер, те стога и ова епизода представља његово симболичко алармирање на поремећени ред. Слично тумачење даје и Сингал, који ову сцену чак тумачи као „климакс Фокнеровог модернистичког ремек дела“, сматрајући да она изражава Фокнеров болан однос према прошлости Југа (према Сингалу, наиме, Бенџи немушто исказује тугу и морални став након што му због Лестеровог неочекованог маневра у видокруг улази статуа војника Конфедерације).

19 Bleikasten y Bloom 2008: 41 - 66. 
на супротан закључак, илуструјући то цитатом из романа о насликаној картонској цркви на ивици „спљоштеног“ призора пејзажа.

То је заиста тмуран предео, „пуста земља“ коју је пролеће заборавило, и њена јаловост, разбијеност и отрцаност необично подсећају на прљава предграђа Нове Енглеске у којима је Квентин шетао са малом Италијанком на дан свог самоубиства. И као и у Квентиновом монологу, јавља се сумња да је овај свет лишен своје супстанце, да није ништа више од оптичке илузије постављене на ивици амбиса или филмични, обмањујући декор који маскира ништавило [...] (Bleikasten y Bloom 2008: 45).

У том смислу би се проповед велечасног Шегога, будући да је реч о мистичком откровењу доступном само црначкој хришћанској заједници, могла тумачити као један од механизама контраста којим се наглашава свет разорене идиле Компсонових. „У регистру имагинарног, мит је за последње поглавље романа оно што је машта за претходне. Прилично налик машти, мит је креирање људске жеље која негира време и смрт.“ (Bleikasten у Bloom: 59). Такође, ова жеља је и жеља за аутентичним људским односима, јер као што каже Блекастан, у етимологији речи религија је веза - веза која спаја човека са човеком и човека са Богом (60).

Општи утисак који ствара унутрашња структура монолога из прва два поглавља (наизменични интервали блеска и губљења идиличног света) рекреира се, у виду оквирног mise en abyme и на плану композиције романа: Осећамо се као да је нам је Фокнер најпре одшкринуо прозор у овај свет, да би га потом грубо залупио пред нашим носом. У анализи са аспекта Бахтиновог хронотопа разорене идиле још једном се дакле потврђује јединство тематике и форме које је тако генијално остварено у Фокнеровом делу. Оштар контраст између два временска плана - трагичне кризе од пре двадесет година и њених ефеката данас изванредно је подвучен стилским и композиционим иновацијама Буке и беса, које уједно дочаравају два стадијума разарања идиле. У насумичним сећањима Бенџија и компулсивним реминисценцијама Квентина насликани су одблесци једног већ изгубљеног света, док духовно осиромашење Џејсоновог монолога и 
„реализам“ Дилсиног ${ }^{20}$ поглавља приказују његове рушевине. Сартр је био сасвим у праву када је рекао да се овај роман не може испричати другачијим редоследом, јер би то онда био другачији роман.

У роману који по оцени критичара представља његово прво модернистичко ремек дело, Фокнер је, експериментишући са књижевном формом, иновирао и традиционални хронотоп разарања идиле, карактеристичан за породични роман и роман генерација. Главне хронотопске целине: идила - разорена идила овде нису изграђене хронолошким следом, већ су из такорећи намерно изломљених делова рекреиране стилским и структурним средствима. Наиме, у испретумбаним епизодама које чине сиже романа у прва два поглавља се стилским и структурним средствима (митолошким обрасцима, понављањем слика и симбола, тема и мотива) рекреира идилични свет, подривен носталгијом због губитка, док се у друга два приказује разорена идила. Иновације у хронотопу настају као резултат Фокнерових иновација на плану романескне форме и наративних техника, и додатно су појачане на тематском плану, односном ликова према времену.

\section{3. Древна суседства}

Бахтин је идилични хронотоп схватао као идилични тип васпостављања фолклорног времена и древног комплекса мотива који су на преткласном земљорадничком стадијуму развоја људског друштва чинили интегралну целину, одражавајући јединство људске заједнице и њену хармонију са природом. У Буцุи и бесу критичари такође препознају ове основне и древне мотиве, примећујући да они граде тематску сродност са Док лежах на самриии: као што напомиње Тредел (Nicolas Tredell), оба романа се „неустрашиво хватају у коштац са фундаменталним феноменима - рођењем, сексуалношћу и смрћу“

20 Усталио се назив „Дилсино поглавље“, иако тачка гледишта четвртог поглавља не припада црној слушкињи Компсонових (поглавље само почиње њеним описом). Као што каже Блекастан, није у питању ни свезнајући наратор, ни непристрасни посматрач. „Наративни приступ је онај који налазимо у многим Фокнеровим романима: слободан и флексибилан, који будно држи пажњу на ономе шта се дешава, док се истовремено ангажује у процесу тумачења“ (Bleikasten у Bloom 2008: 41). Блекастан то даље илуструје указујући на понављање компаративно-кондиционалних реченица или речи и фраза које означавају несигурност. 
(Tredell 1999: 7). Такође, оба романа су уско фокусирана на породичне односе, скоро сасвим изоловане од друштвено-историјског контекста, и у њима те основне реалности људског живота добијају посебну тежину, па чак и митске пропорције.

Прва два поглавља Буке и беса, у којима се рекреира идилични свет, деле ове заједничке древне мотиве (сексуалност, рођење (трудноћа), венчање, смрт, природа), али се са преласком са Бенџијевог на Квентиново унутрашње доживљавање доминанта читаве слике мења - код Бенџија целину ипак уоквирава живот, успостављајући јединство између ових древних мотива, док је код Квентина доминанта смрт, која ствара непремостиве контрасте. Бенџијева ограничена могућност резоновања онемогућава повлачење оштрих граница и смрт приказује као део живота, омогућавајући да осетимо неко заборављено сродство између ових мотива. На пример, сцена у којој се Кеди пење на крушку да би видела и осталој деци пренела на који начин се то одрасли односе према смрти, у моменту када Фрони шапуће „Шта видите“, у Бенџијевој свести се претапа у сцену са Кединог венчања: „Ја сам их вияео. Онда сам вияео Кеgи са цвећем у коси, и с јеgним gуіачким велом сличним блистиавом вет̄ру. Кеgи. Кеgи. " (Faulkner 2001: 58). Блекастан указује да, будући да наративни ред Бенџијевог поглавља није синтагматски (метонимијски) већ парадигматски (метафорички),

сцене или делови сцена који су одвојени у времену теже да се групишу и да формирају ланце на основу њихових заједничких елемената [...] А ови ланци су пак са своје стране интегрисани у веће комплексе значења. Тако повезивање четири епизоде смрти са Кединим венчањем указује на сличан значај ових догађаја за Бенџија у смислу губитка и најављује метафоричко изједначавање секса и смрти које је у основи другог поглавља. (Bleikasten 1990: 1901)

Метафоричко повезавање у оквиру већих комплекса значења можемо објаснити и као рекреирање архетипског извора, јединства бахтиновског фолклорног хронотопа.

Целокупан стил Бенџијевог поглавља имитира живот који иде напред: преовлађује језик осетилног искуства и уверљиви, животни 
дијалози, а сретне и тужне епизоде неумољиво смењују једна другу. (Иначе, критичари су често наглашавали и „објективност“ Бенџијевог приказа упоређујући га са камером и истичући да он претендује да прикаже непосредно, нерефлектовано искуство). Иако је идилично јединство донекле подривено самим контекстом, јер је упркос ведром и животном тону целине читалац у позадини свестан чињенице да је реч о сећањима једног идиота, целовитост Бенџијеве слике ипак остаје очувана до последње сцене романа.

У Квентиновом поглављу такође срећемо низове истих древних мотива (нпр. сексуалности и смрти, сексуалности и природе), али је њихово јединство све време подривано насилним цепањем тока перцепције или резоновања и ерупцијом нихилистичких опсесија у Квентиновој свести. Као и у другим аспектима, и у овом погледу су црнци приказани као противтежа Квентиновом подељеном уму, па тако црнац Луис Хачер снажно евоцира јединство човека са природом карактеристично за фолклорни хронотоп. Његово примитивно, магијско веровање „да може да одврати катастрофу просто тако што ће се старати да његов фењер буде чист“" противтежа је Квентиновом расцепу и „представља, укратко, алтернативни идентитет, чврсто укорењен у физичкој реалности и људској заједници за којим белци са Југа из добрих породица као Квентин кришом жуде - управо стога му се Квентинове мисли враћају, безуспешно покушавајући да пробију баријеру расе како би докучили његову тајну“ (Singal у Bloom 2008: 93).

Разлика у третирању древних суседстава између Бенџијевог и Квентиновог поглавља је управо она коју Бахтин препознаје између књижевности ренесансе (нпр. Раблеа, Бокача, Шекспира) и романтизма и симболизма. Бахтин као контраст Раблеу наводи једну Поову ренесансну новелу (Бачва амонйиљьgа) која обрађује исте мотиве, али у којој „изостаје здрав победнички живот који уоквирава целину““, тако да остају „голи, безизлазни и зато језиви контрасти“ (Бахтин 1989: 323). Сличне језиве контрасте срећемо у Квентиновим надреалним сликама. Његова слика смрти као „личног и нарочитог пријатеља“ његовог деде, који заједно са њим, „на једној узвишици иза кедрова“ седи и разговара „чекајући на старога пуковника Сарториса да седне са њима“" (Faulkner 2001: 181) савршено би пристајала контексту идиле и неком достојанственом старцу који у смирај живота 
прихвата свој скори крај као део природног и генерацијског циклуса. Када пак схватимо на какав састанак се детаљно спрема овај сензитивни и интелигентни младић, опседнут педантеријом (вративши се у последњем часу, кад се већ ухватио за кваку, да опере зубе и бринући да очетка свој шешир) и опсесивно пазећи да не закасни као да га чека вољена драгана, обузима нас ништа мањи ужас него у Поовој причи у којој јунак свог противника живог зазидава винском подруму за време карневала, где је последње што овај чује смех и звон лакрдијашких прапораца (Бахтин 1989: 323). И ми се осећамо као да смо преваром намамљени у исти такав подрум, упркос Квентиновим злослутним наговештајима кроз читаво поглавље, јер смо и за време његовог монолога успевали да из изломљених фрагмената саградимо слику једног дивног, мада изгубљеног света ${ }^{21}$. Када је реч о Бенџијевој целини, она се потпуно распада тек у последњој сцени романа, што је такође изванредан Фокнеров захват - да створену илузију - илузију у чијем стварању смо и сами учествовали (због структурних захтева Бенџијевог поглавља) на известан начин чува ненарушену до самог краја, кроз сву голготу трећег и четвртог поглавља, да би нам је онда грубо одузео. „Скренувши на погрешну страну“ Фокнер нас оставља ништа мање ојађеним него Бенџија.

Као што је још Сартр увидео, главно значење Буке и беса, метафизика која крије кључ његове естетике и форме, може се исказати као метафизика времена. На Бахтиновом трагу ми бисмо ову метафизику пак преименовали у хронотоп, конкретно хронотоп разорене идиле.

21 Интересантно је да Сартр такође детектује ову Фокнерову превару, то јест „непоштење“ које он у склопу свог аргумента тумачи као маневар којим Фокнер својим ликовима одузима будућност, односно могућност делања и слободе. Ова превара је омогућена временском перспективом коју је Фокнер одабрао како би представио унутрашњи живот већ мртвог човека - бирајући као садашњост инфинитезимални тренутак смрти: „Тако, кад Квентиново сећање почиње да ређа његове успомене [...] - он је већ мртав. Толика вештина, да кажемо истину, толико непоштење, имају дакле само један циљ: да замене интуицију будућности која аутору недостаје“ (Sartre 1984: 192). У овом контексту је индикативан и однос идентификације/дистанце између читаоца и различитих наратора у Буц̧и и бесу. Блекастан истиче да, за разлику од Џејсоновог монолога, у коме је „могућност идентификације подривена иронијом романописца“", са Квентином се најпре идентификујемо, а тек кад боље размислимо почињемо да критички посматрамо лик“(Bleikasten 1990: 2759). 
Критичари су већ приметили да када је оптужио Фокнера да је „обезглавио“ време одузевши му будућност, Сартр је неоправдано изједначио Фокнерово виђење времена са Квентиновим ${ }^{22}$. Ми пак сматрамо да се на замерке које Сартр упућује америчком романописцу може одговорити у контексту Фокнеровог покушаја да на иновативан начин реализује један традиционални жанровски хронотоп. У контексту приказивања хронотопа разорене идиле могу се објаснити и опсесивна фокусираност на прошлост, односно укидање будућности, као и специфична природа садашњости у Буц̧и и бесу. („Ова недефинљива садашњост; ове изненадне инвазије прошлости; овај афективни поредак супротстављен рационалном поретку коме, иако је хронолошки, недостаје реалност“) (Sartre 1984: 229).

Фокнер је увидео да нема бољег начина да истакне суморну садашњост разорене идиле него да рекреира изгубљени идилични свет и дозволи да га на тренутак искусимо, јер ће тиме до неиздрживости појачати осећај носталгије и губитка. Његов генијални потез представља одабир прва два приповедача у чијој свести (па тако и у свести читаоца, који нема дистанцу јер је приповедање у првом лицу ${ }^{23}$ ) тај свет бива најнепосредније и најреалније рекреиран. У Бенџијевом и Квентиновом монологу тај идилични свет је суштинска реалност која има смисла и чији афективни поредак је једини супстанцијалан - бледа садашњост је заиста уљез који нас однекуд необјашњиво спопада. Када потом добијемо чврсте сигнале да је реч о непостојећој целини, креираној у мозгу једног идиота и самоубице, секунду пред смрт, и даље не пристајемо да успоставимо прави, хронолошки поредак. Чежња због губитка је толико интензивна, а „пуста земља“ ${ }^{\text {“24 }}$ трећег и четвртог поглавља толико сушна, да поприма надреални квалитет. Није ствар у томе да нас метафизика романа спречава да успостави-

22 Види нпр. претпоследњи пасус поглавља Of Time and the Unreal; Quentin's Time (Bleikasten).

23 Фокнер је такође, појачавајући читаочево ангажовање у стварању смисла у Бенџијевом поглављу додатно појачао његов „осећај власништва“. Види између осталих: Owen Robinson, прво поглавље Creating Yoknapatawpha (2006).

24 Поређење Буке и беса са Елиотовом Пусйом земљом је опште место у критици. Види, између осталих: Robert Pen Warren 1966: 269, Donald Kartiganer 1979:135, Andre Bleikasten y Bloom 2008: 45. 
мо прави поредак између прошлости, садашњости и будућности, већ сасвим неочекивано, преварени Фокнеровим мајсторским захватом, налазимо себе у ситуацији да, попут Бенџија и Квентина, ни не желимо да га успоставимо.

\section{ЛИТЕРАТУРА}

Bahtin M. (1989). O romanu (preveo Aleksandar Badnjarević). Beograd: Nolit. Bauer M.D. (2000). I have sinned in that I have betrayed the innocent blood: Quentin's Recognition of His Guilt, in: Southern Literary Journal 32.2 (2000): 70-82.

Bleikasten A. (1990). The Ink of Melancholy: Faulkner's Novels from The Sound and the Fury to Light in August. Bloomington: Indiana University Press.

Bloom H. (2008) (ed). Modern Critical Interpretations: William Faulkner's The Sound and the Fury. New York: Infobase Publishing.

Brooks C. (1963). William Faulkner, The Yoknapatawpha Country. New Haven and London: Yale University Press.

Burton S. (2001). Rereading The Sound and the Fury, in: Modern Philology, May 2001, Vol. 98 Issue 4, p 604. 25p.

Kartiganer D. (1979). The Fragile Thread: The Meaning of Form in Faulkner's Novels, Amherst: University of Massachussets Press.

Minter D. (2001). Faulkner's Questioning Narratives: Fiction of his Major Phase 1929-42. Urbana and Chicago: University of Illinois Press.

Thomson L. (1963). Mirror Analogues in The Sound and the Fury, in: Hoffman, Frederick and Vickery, Olga (eds.), William Faulkner: Three Decades of Criticism. New York and Burlingame: Harcourt, Brace and World Inc.

Puillon J. (1966). Time and Destiny in Faulkner, in: Robert Penn Warren (ed.), A Collection of Critical Essays. pp 79 -86. Englewood Cliffs, NJ: Prentice.

Tredell N. (1999). William Faulkner: The Sound and the Fury, As I Lay Dying. New York: Columbia University Press.

Robinson O. (2006). Creating Yoknapatawpha: Readers and Writers in Faulkner's Fiction, New York and London: Routledge.

Sartre J.P. (1984). Povodom "Buke i besa": temporalnost kod Foknera, u: Šta je književnost, Beograd: Nolit.

Stevenson R. (1992). Modernist Fiction: An Introduction. London: Harvester Wheatsheaf. 
Storhoff G. (1988). Faulkner's Family Crucible: Quentin's Dilemma, in: Mississippi Quarterly. 51:3-4.

Vidan I. (1971). Romani struje svijesti, Zagreb: Školska knjiga.

Warren R.P. (1966). Faulkner: The South, the Negro and Time in: Robert Penn

Warren (ed.), Faulkner: A Collection of Critical Essays, pp 251-271. Englewood Cliffs, N.J: Prentice.

\title{
Извори
}

Faulkner W. (2001). Buka i bes (preveo Božidar Marković). Beograd: Zavod za udžbenike i nastavna sredstva.

\section{Svetlana D. Mladenović}

\author{
CHRONOTOPE OF THE DESTRUCTION \\ OF THE IDYLL IN THE SOUND AND THE FURY
}

\section{Summary}

In the analysis of The Sound and the Fury, Faulkner's first modernist novel that inaugurated the discussion about the use of time in his work, we started from the novel's genre, in order to apply Bakhtin's chronotope of the destruction of the idyll. While endorsing Sartre's insights about the nature of time in The Sound and the Fury, we put them in a different framework - chronotope of the destruction of the idyll - thereby enabling a radically different reading.

We showed that Faulkner's treatment of time in The Sound and the Fury, rather than reflecting a nihilist metaphysics, actually serves the function of amplifying and innovating the traditional chronotope of the destruction of the idyll by structural and stylistic means. By using narrative techniques innovative for his time - stream of consciousness for depicting the worldviews of intellectually challenged Benjy and suicidal Quentin, Faulkner succeeded to create a specific sense of time that in an innovative manner builds the chronotope of the destruction of the idyll. The no-longer-existing idyllic world is not placed in some idealised past, but constantly unexpectedly emerges in Benjy's consciousness, invoked by associations, and erupts in Quentin's, provoked by his obsessions, and exiling his present.

The general impression created by the internal structure of monologues from the first two chapters (alternating intervals of flashes and disappearances of 
the idyllic world) is recreated, in the form of mise-en-abyme, also in the novel's composition. The analysis through the lenses of Bakhtin's chronotope of the destruction of the idyll once again confirms the genius achievement of unity of theme and form in Faulkner's work, first detected by Conrad Aiken ${ }^{25}$. The stark contract between two time planes - the tragic crisis from twenty years ago and its effects today is remarkably emphasised by stylistic and compositional innovations of The Sound and the Fury, which at the same time recreate two stages - idyll and destruction of the idyll.

In the novel which critics dubbed his first modernist masterpiece, by experimenting with the literary form, Faulkner also innovated the traditional chronotope of the destruction of the idyll, characteristic for the family novel and the novel of generations. The main chronotopic wholes: idyll - destroyed idyll are not built in chronological order, but are recreated by stylistic and structural means from intentionally broken fragments. Namely, in chronologically shuffled episodes which make up the novel's sujet, the first two, by stylistic and structural means (derealisation of present on account of the past, mythological patterns, repetitions of images and symbols, themes and motives), work toward recreating the idyllic world, undermined by nostalgia over loss, while the second two episodes depict the destroyed idyll. Innovations in the chronotope emerge as a result of Faulkner's innovations on the plane of novelistic form and narrative techniques and are additionally amplified on the thematic plane, by characters' relationship toward time.

Keywords: The Sound and the Fury, chronotope of the destruction of the idyll, time, Faulkner, Sartre, Bakhtin.

25 Aiken, Conrad, "William Faulkner: The Novel as Form“ (1963). 